\title{
Correlation and Path Coefficient Analysis in Elite Germplasm of Rice (Oryza sativa L.)
}

\author{
R. Sivasankar*, B.G. Suresh, S. Ashish and T.R. Sudheer \\ Department of Genetics and Plant Breeding, SHUATS, Allahabad, India \\ *Corresponding author
}

A B S T R A C T

Keywords

Rice (Oryza sativa L.), Genotypic,

Phenotypic, Correlation and Path analysis

Article Info

Accepted:

26 June 2018

Available Online:

10 July 2018
The present investigation consists of 35 rice genotypes including one check, which were obtained from Department of Genetics and Plant Breeding, SHUATS, Allahabad. The experiment was conducted during Kharif2017in RBD with three replications. The data were recorded for 13 quantitative characters to study Correlation and Path analysis. Analysis of variance revealed that there is considerable variability among the genotypes. Genotypes were found best on the basis of grain yield per hill, OM-6070 followed by CT18148-6-9-5-1-2MMP and NDR-1045 (2\% EMS). Correlation coefficient analysis revealed that days to $50 \%$ flowering, plant height, tillers per hill, panicles per plant, flag leaf width, flag leaf length, spikelet's per panicle, days to maturity, biological yield and harvest index, test weight showed positive significant correlation with grain yield at both genotypic and phenotypic level. Path analysis indicated that panicle length, flag leaf width, spikelet's per panicle, days to maturity, biological yield and harvest index, test weight had high positive direct effect on grain yield per hill at both genotypic and phenotypic level. Thus, these traits are identified as the efficient and potential for indirect selection for the improvement of rice productivity in the present experimental materials.

\section{Introduction}

Rice (Oryza sativa L.) is the world's second most important staple cereal food crop for more than half of the global population providing about $75 \%$ of the calorie and $55 \%$ of the protein intake in their average daily diet and aptly describes the slogan "Rice is life". More than 90 per cent of the world's rice is grown and consumed in Asia, known as rice bowl of the world, where 60 percent of the earth's people and two thirds of world's poor live (Diwedi et al., 2015) about 2.5 billion world's population which may escalate to 4.6 billion by the year 2050 (Meena et al., 2015). Rice is also called as the "Grain of Life", because it is not only the staple food for more than 70 per cent of the Indians but also a source of livelihood for about 120-150 million rural households.

In India rice growing over an area of $44.8 \mathrm{mha}$ with production of $104 \mathrm{mt}$. In 1950's the Indian population is around 35 to 40 crores and the current India's population is reaching 120 crores. In India demand for rice will be 
121.2 million tons by the year 2030 for internal consumption (Directorate of Rice Research Annual Report 2016-17). It may be due to industrialisation and urbanization most of the fertile crop fields are gradually turning into normal lands and there is less scope for increasing area under crop fields. From 1970's due to continuous use of same varieties over the long period of years, there was huge yield stagnation. In order to break yield gap and for developing high yielding varieties genetic variability is one of the foremost important breeding tool.

Crop improvement in rice depends on the magnitude of genetic variability and extent to which desirable genes are heritable. The use of correlation coefficient is to establish the extent of association between yield and yield component and other characters, which are having decisive role in influencing the yield. Partitioning of total correlation into direct and indirect effects by path coefficients analysis helps in making the selection more effective.

\section{Materials and Methods}

The present investigation was carried out to measure the character association and path coefficients using 35 elite genotypes of rice. The present investigation was carried out in the Field Experimentation Centre of Department of Genetics and Plant Breeding, Naini Agricultural Institute, Sam Higginbottom University of Agriculture, Technology and Sciences, Allahabad, U.P, India during kharif, 2017.The experimental trial was laid out in Randomized Block design with three replications under irrigated conditions which is located at $25.57^{0} \mathrm{~N}$ latitude, $81.51^{0} \mathrm{E}$ longitude and 98 meter above the sea level.. Twenty four days old seedlings of each genotype were transplanted in three rows of 3.0 metres length by adopting a spacing of $20 \times 15 \mathrm{~cm}$ between row to row and plant to plant. Standard agronomic practices were followed throughout the crop growth period to raise a good crop. Observations were recorded on 10 randomly selected plants for thirteen metric traits viz., Plant height, Number of tillers per hill, Number of panicles per hill, Panicle length, Flag leaf length, Flag leaf width, Number of spikelet's per panicle, Biological yield per hill, Harvest index, Test weight, Grain yield per hill in each replication. Days to $50 \%$ flowering and days to maturity were recorded on plot basis.

Phenotypic and genotypic correlations were worked out by using the formulae suggested by Falconer (1964). The partitioning of genotypic and phenotypic correlation coefficient in to direct and in direct effects was carried out using the procedure suggested by Dewey and Lu, (1959). The estimated values were compared with table values of the correlation coefficient to test the significance of the correlation coefficient prescribed by Fisher and Yates (1963).

\section{Results and Discussion}

Correlation studies in the breeding material will help in developing a selection scheme, which would help in enhancing the genetic potential of a crop. It also provides reliable information in nature extent and the direction of the selection especially when the breeder needs to combine high yield potential with desirable traits and seed quality characters. In the present investigation the genotypic and phenotypic correlation coefficient of different characters with seed yield per plant and their relationship among themselves are presented in table 1. In general genotypic correlation was higher in magnitude than the phenotypic correlation coefficient. This indicates that these characters are positively governed by additive of gene action and are useful in improvement. This is in agreement with the findings reported by Kole et al., (2008). 
Table.1 Correlation coefficient between yield and its related traits in 35 rice genotypes

\begin{tabular}{|c|c|c|c|c|c|c|c|c|c|c|c|c|c|c|}
\hline $\begin{array}{c}\text { S.N } \\
0\end{array}$ & Character & $\begin{array}{c}\text { Days to } \\
50 \% \\
\text { Flowering }\end{array}$ & $\begin{array}{l}\text { Plant } \\
\text { Height } \\
(\mathrm{cm})\end{array}$ & $\begin{array}{c}\text { No. of } \\
\text { tillers/ } \\
\text { Hill }\end{array}$ & $\begin{array}{c}\text { No. of } \\
\text { panicles } \\
\text { / Hill }\end{array}$ & $\begin{array}{l}\text { Panicle } \\
\text { Length } \\
\text { (cm) }\end{array}$ & $\begin{array}{l}\text { Flag } \\
\text { Leaf } \\
\text { length } \\
(\mathrm{cm})\end{array}$ & $\begin{array}{c}\text { Flag } \\
\text { Leaf } \\
\text { width } \\
(\mathrm{cm})\end{array}$ & $\begin{array}{c}\text { No. of } \\
\text { Spikelets } \\
\text { / } \\
\text { panicle }\end{array}$ & $\begin{array}{l}\text { Days to } \\
\text { Maturity }\end{array}$ & $\begin{array}{l}\text { Biological } \\
\text { Yield/ } \\
\text { Hill } \\
(\mathrm{g})\end{array}$ & $\begin{array}{c}\text { Harvest } \\
\text { index } \\
(\%)\end{array}$ & $\begin{array}{c}\text { Test } \\
\text { weight } \\
\text { (g) }\end{array}$ & $\begin{array}{c}\text { Grain } \\
\text { Yield/ Hill } \\
(\mathrm{g})\end{array}$ \\
\hline 1. & Days to $50 \%$ Flowering & 1.00 & $0.50 * *$ & 0.05 & 0.16 & -0.01 & $0.20 *$ & $0.35^{* *}$ & $0.60 * *$ & $0.96 * *$ & $0.31 * *$ & $0.58 * *$ & -0.02 & $0.54 * *$ \\
\hline 2. & Plant Height (cm) & & 1.00 & 0.16 & $0.23 *$ & $-0.20 *$ & 0.09 & $0.33 * *$ & $0.55^{* *}$ & $0.53 * *$ & 0.14 & $0.31 * *$ & -0.10 & $0.28 * *$ \\
\hline 3. & No. of Tillers / Hill & & & 1.00 & $0.68 * *$ & -0.02 & -0.07 & $0.27 * *$ & 0.06 & 0.02 & $0.36 * *$ & $0.28 * *$ & $-0.21 *$ & $0.34 * *$ \\
\hline 4. & No. of Panicles/ Hill & & & & 1.00 & 0.06 & 0.09 & $0.27 * *$ & 0.11 & 0.14 & $0.43 * *$ & $0.34 * *$ & $-0.20 *$ & $0.41 * *$ \\
\hline 5. & Panicle Length (cm) & & & & & 1.00 & $0.44 * *$ & -0.08 & $-0.23 *$ & 0.02 & $0.30 * *$ & -0.04 & $0.28 * *$ & 0.12 \\
\hline 6. & Flag Leaf Length (cm) & & & & & & 1.00 & $0.26 * *$ & 0.12 & $0.19 *$ & $0.54 * *$ & 0.15 & $0.20 *$ & $0.35 * *$ \\
\hline 7. & Flag Leaf Width (cm) & & & & & & & 1.00 & $0.25 * *$ & $0.33 * *$ & $0.19 *$ & $0.24 *$ & -0.04 & $0.26 * *$ \\
\hline 8. & No. of Spikelets/Panicle & & & & & & & & 1.00 & $0.62 * *$ & $0.25 * *$ & $0.65^{* *}$ & -0.13 & $0.56 * *$ \\
\hline 9. & Days to Maturity & & & & & & & & & 1.00 & $0.26 * *$ & $0.57 * *$ & -0.03 & $\mathbf{0 . 5 1} * *$ \\
\hline 10 & Biological Yield (g) & & & & & & & & & & 1.00 & $0.45^{* *}$ & $0.32 * *$ & $0.79 * *$ \\
\hline 11 & Harvest Index (\%) & & & & & & & & & & & 1.00 & 0.18 & $0.87 * *$ \\
\hline 12 & Test Weight (g) & & & & & & & & & & & & 1.00 & $\mathbf{0 . 3 1} * *$ \\
\hline
\end{tabular}


Table.2 Direct and indirect effects for different quantitative characters on grain yield

\begin{tabular}{|c|c|c|c|c|c|c|c|c|c|c|c|c|c|c|}
\hline S.No & Character & $\begin{array}{l}\text { Days to } \\
50 \% \\
\text { Flowering }\end{array}$ & $\begin{array}{l}\text { Plant } \\
\text { Height }\end{array}$ & $\begin{array}{l}\text { Tillers / } \\
\text { Plant }\end{array}$ & $\begin{array}{l}\text { Panicles/ } \\
\text { Plant }\end{array}$ & $\begin{array}{l}\text { Panicle } \\
\text { Length }\end{array}$ & $\begin{array}{l}\text { Flag } \\
\text { Leaf } \\
\text { Length }\end{array}$ & $\begin{array}{l}\text { Flag } \\
\text { Leaf } \\
\text { Width }\end{array}$ & $\begin{array}{l}\text { Spikelet's/ } \\
\text { Panicle }\end{array}$ & $\begin{array}{l}\text { Days to } \\
\text { maturity }\end{array}$ & $\begin{array}{l}\text { Biological } \\
\text { Yield }\end{array}$ & $\begin{array}{l}\text { Harvest } \\
\text { Index }\end{array}$ & $\begin{array}{l}\text { Test } \\
\text { Weight }\end{array}$ & $\begin{array}{l}\text { Seed } \\
\text { Yield/ } \\
\text { Plant }\end{array}$ \\
\hline 1. & $\begin{array}{l}\text { Days to } 50 \% \\
\text { Flowering }\end{array}$ & -0.1145 & -0.0579 & -0.0065 & -0.0189 & 0.0022 & -0.0240 & -0.0408 & -0.0696 & -0.1110 & -0.0361 & -0.0670 & 0.0026 & 0.5430 \\
\hline 2. & Plant Height & -0.0037 & -0.0072 & -0.0012 & -0.0017 & 0.0015 & -0.0007 & -0.0024 & -0.0040 & -0.0039 & -0.0010 & -0.0023 & 0.0008 & 0.2813 \\
\hline 3. & Tillers / Hill & -0.0011 & -0.0034 & -0.0202 & -0.0138 & 0.0005 & 0.0015 & -0.0056 & -0.0013 & -0.0005 & -0.0074 & -0.0058 & 0.0043 & 0.3483 \\
\hline 5. & Panicle Length & -0.0001 & -0.0007 & -0.0001 & 0.0002 & 0.0034 & 0.0015 & -0.0003 & -0.0008 & 0.0001 & 0.0010 & -0.0001 & 0.0010 & 0.1233 \\
\hline 6. & Flag Leaf Length & -0.0109 & -0.0049 & 0.0038 & -0.0048 & -0.0230 & -0.0519 & -0.0137 & -0.0064 & -0.0102 & -0.0284 & -0.0082 & -0.0106 & 0.3591 \\
\hline 7. & Flag Leaf Width & 0.0084 & 0.0079 & 0.0065 & 0.0064 & -0.0019 & 0.0062 & 0.0234 & 0.0060 & 0.0079 & 0.0047 & 0.0058 & -0.0010 & 0.2654 \\
\hline 8. & $\begin{array}{l}\text { Spikelet's/ } \\
\text { Panicle }\end{array}$ & 0.0192 & 0.0175 & 0.0020 & 0.0036 & -0.0074 & 0.0039 & 0.0080 & 0.0316 & 0.0199 & 0.0081 & 0.0206 & -0.0043 & 0.5675 \\
\hline 10. & Biological Yield & 0.1707 & 0.0780 & 0.1980 & 0.2337 & 0.1634 & 0.2964 & 0.1077 & 0.1382 & 0.1432 & 0.5420 & 0.2473 & 0.1787 & 0.7995 \\
\hline 11. & Harvest Index & 0.3620 & 0.1946 & 0.1790 & 0.2118 & -0.0258 & 0.0983 & 0.1541 & 0.4039 & 0.3560 & 0.2823 & 0.6188 & 0.1141 & 0.8799 \\
\hline 12. & Test Weight & -0.0006 & -0.0030 & -0.0059 & -0.0056 & 0.0079 & 0.0057 & -0.0012 & -0.0038 & -0.0009 & 0.0091 & 0.0051 & 0.0276 & 0.3123 \\
\hline
\end{tabular}


Grain yield per plant showed the positive significant phenotypic and genotypic association with Harvest index $(0.87 * *)$, Biological yield $\left(0.79^{* *}\right)$, Number of spikelet's per panicle $\left(0.56^{* *}\right)$, Days to $50 \%$ flowering $\left(0.54^{* *}\right)$, Days to maturity $\left(0.51^{* *}\right)$, Number of panicles per hill $\left(0.41^{* *}\right)$, Flag leaf length $\left(0.35^{* *}\right)$, Number of tillers per hill $(0.34 * *)$, Test weight $\left(0.31^{* *}\right)$, Plant height $(0.28 * *)$, Flag leaf width $\left(0.26^{* *}\right)$. The correlation does not showed negative significant and negative nonsignificant association. The character like panicle length (0.12) correlation shows positive non-significant.

Path coefficient analysis splits the correlation coefficient into the measure of direct and indirect effect i.e., direct and indirect contribution of various independent characters on a dependent character. The result obtained has been presented in Table 2 . The high positive direct effects on Grain yield per hill were exerted by Biological yield per hill and Harvest index thus these characters emerged as most important direct yield components on which emphasis should be given during simultaneous selection aimed at improving grain yield of rice. These characters have also been identified as major direct contributors towards grain yield by Ashish et al., (2018), Kishore et al., (2018) and Kalyan et al., (2017). Biological yield hill $^{-1}$ exerted considerable positive indirect effects on all the quantitative parameters taken in the present study. Harvest-index had positive indirect effect on all the parameters except Panicle length. Devi et al., (2017), Dhurai et al., (2016) have also identified biological yield per hill and harvest index as most important yield contributing traits which merit due consideration at the time of devising selection strategy aimed at developing high yielding varieties in rice.

In conclusion, correlation coefficient analysis revealed that days to $50 \%$ flowering, plant height, tillers per hill, panicles per plant, flag leaf width, flag leaf length, spikelet's per panicle, days to maturity, biological yield and harvest index, test weight showed positive significant correlation with grain yield at both genotypic and phenotypic level. Path analysis indicated that panicle length, flag leaf width, spikelet's per panicle, days to maturity, biological yield and harvest index, test weight had high positive direct effect on grain yield per hill at both genotypic and phenotypic level. A critical analysis of correlation indicated that emphasis should be directed towards selection of parents having higher number of productive tillers per plant coupled with higher number of filled grains per panicle, 1000 grain weight, plant height and panicle length also. As the yield component, filled grains per panicle are intern dependent on panicle length and plant height, attention should be towards increasing the panicle length, maintaining optimum plant height. Thus, a plant with medium height, sturdy culm with increased panicle length, higher number of filled grains per panicle and productive tillers per plant would be more desirable for selection to realize higher yield.

\section{References}

Ashish, K.P., Bharathi, M. and Kumaravadivel, N. (2018). Genetic variability and character association studies in advanced backcross generation of rice (Oryza sativa L.). Journal of pharmacognosy and phytochemistry.7 (1): 2397-2400.

Devi, R.K., Satish, C.B., Lingaiah, N., Hari, Y. and Venkanna, V. (2017). Analysis of variability, correlation and path coefficient studies for yield and quality traits in rice (Oryza sativa $\mathrm{L}$.). Agricultural science digest. 37 (1): 19.

Dewey, D.R. and Lu, K.H. (1959). Genetic variability, correlation and path coefficient analysis of components of 
crested wheat grass seed production. Agronomic Journal.51: 515-518.

Dhurai, S.Y., Bhati, P.K. and Saroj, S.K. (2016). Studies on genetic variability for yield and quality characters in rice (Oryza sativa L.) under integrated fertilizer management. An International quarterly Journal of Life Sciences, 9 (2): 845-848.

Directorate of Rice Research Annual Report 2016-17.

Dwivedi, R., Srivastava, K., Devi, A., Kumari, P. and Dwivedi, D.K. (2015). Genetic Variability in Rice Under Saline Condition. Trends in Biosciences. 8 (15): 3881- 3887.

Falconer, D.S. (1964). Introduction to quantitative genetics Edinburgen and London: Aliver and Bodyd.

Fisher, R.A., Yates, F. (1967). Statistical tables for biological, Agricultural and medical Research, Congress Group Limited, London.

Kalyan, B., Radha Krishna, K.V. and Rao, L.V.S. (2017). Correlation coefficient analysis for yield and its components in rice (Oryza sativa L.) genotypes. International journal of current microbiology and applied sciences. 6 (7): 2425-2430.

Kishore, C., Anil, K., Awadhesh, K., Vinod,
K., Prasad, B.D. and Anand, K. (2018). Character association and path analysis for yield components in traditional rice (Oryza sativa L.) genotypes. International journal of current microbiology and applied sciences. 7 (3): 456-460.

Meena, A.K., Suresh, J., Mahanthesha, M., Meena, H.P. (2015). Genetic variability, heritability and genetic advance for yield and yield components in rice (Oryza sativa L.). The Bioscan. 9 (3\&4): 1053-1056.

Nandan, R. and Shravan, K.S. (2018). Character association and path analysis in rice (Oryza sativa L.) genotypes. Agricultural science digest. 37 (3): 1012-1017.

Nuruzzaman, M., Hasan, L., Shamsun, N.B. and Huda, M.H. (2017). Correlation and path coefficient analysis of yield components in NERICA mutant rice lines under rainfed conditions. Journal of experimental agriculture international. 16 (1): 1-8.

Sowmiya, C.A. and Venkatesan, M. (2017). Studies on correlation and path coefficient analysis in rice (Oryza sativa L.). International journal of current microbiology and applied sciences. 6 (9): 1757-1763.

\section{How to cite this article:}

Sivasankar, R., B.G. Suresh, S. Ashish and Sudheer, T.R. 2018. Correlation and Path Coefficient Analysis in Elite Germplasm of Rice (Oryza sativa L.). Int.J.Curr.Microbiol.App.Sci. 7(07): 3454-3459. doi: https://doi.org/10.20546/ijcmas.2018.707.400 